\title{
Genetic variability and field performance of some sweet gourd (Cucurbita moschata Duch) accessions
}

\section{Most. Altaf-Un- Nahar ${ }^{1}$, Shahnaz Begum² ${ }^{2}$, M. G. Rabbani ${ }^{1}$ and Md. Rezaul Karim $^{1}$}

${ }^{1}$ Dept. of Horticulture, Bangladesh Agricultural University, Mymensingh; and Exim Bank Bangladesh Agricultural University, Chapai-Nawabgonj

${ }^{2}$ Rural Reconstruction Foundation (RRF), Jessore, Bangladesh

\begin{tabular}{l}
\hline Article info. \\
\hline Key Words: \\
Genotypes, Genetic divergence \\
and Sweet gourd
\end{tabular}

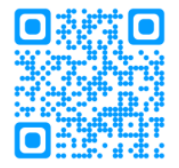

Received: 10.10 .2016

Published: 14.12.2016

For Any Information: ask.author@journalbinet.com

\begin{abstract}
The experiment was conducted at the field and laboratory of "Collection, Evaluation, Conservation and Utilization of Landraces and Wild relatives of Some Important Vegetables and Fruits in Bangladesh (CVFB)" project, Department of Horticulture, Bangladesh Agricultural University, Mymensingh. Studies on field performance and genetic variability of sweet gourd accessions were carried out using morphological traits. Analysis of variance for different characters showed high degree of variation among the 43 accessions. The accession CM152 showed the best performance in respect of yield per plant $(57.8 \mathrm{~kg})$. The highest average fruit weight $(10.43 \mathrm{~kg})$ was recorded in CM154. Regarding the number of fruits per plant, CM145 produced the maximum number of fruits per plant (10.0). In all the traits genotypic coefficient of variation was smaller than phenotypic coefficient of variation. High heritability with genotypic and phenotypic coefficient of variation was observed for vine length at final harvest, number of male flowers per plant, node for first male flowers, average fruit weight, fruit cavity length and breadth, dry weight of 100 $g$ flesh and number of seeds per fruit indicating additive gene effects of these traits.
\end{abstract}

Citation: Nahar, M. A., Begum, S., Rabbani, M. G. \& Karim, M. R. (2016). Genetic variability and field performance of some sweet gourd (Cucurbita moschata Duch) accessions. Journal of Science, Technology and Environment Informatics, 04(02), 301-312.

(C) 2016, Nahar et al. This is an open access article distributed under terms of the Creative Common Attribution 4.0 International License.

\section{Introduction}

Sweet gourd (Cucurbita moschata Duch) is an important vegetable in Bangladesh as well as in the world (Nahar et al., 2005; Tsivelikas et al., 2009; Ghobary and Ibrahim, 2010; Formisano et al., 2012). Sweet 
gourd is a rich source of carbohydrate and contains considerable amount of vitamins, especially high carotenoid pigments and minerals (Bose and Som, 1986). The fruits are consumed at immature and mature stages. The leaves and tender stem are also used as nutritious vegetables. It is grown in all the districts of Bangladesh round the year but its production is concentrated during summer season. It has got good storage potential and well matured fruits can be stored for 2 to 4 months (Yawalkar, 1985). Due to its good taste and keeping quality, nutritional status, easier cooking quality, reasonable market price and year round availability, the demand of sweet gourd is increasing day by day in Bangladesh. It is worth mentioning that there has not been any recommended variety of sweet gourds with high yield potential and better quality in Bangladesh (Nahar et al., 2005; Rashid, 1993). Although, the sweet gourd is the most common vegetable crop in Bangladesh, limited attempt had been made for its genetic improvement. There exists a lot of variability in morpho-agronomic characteristics which have very important effects on the yield of sweet gourd and a good number of cultivars and landraces are grown all over the country in the homestead and also in the field (Hamid et al., 1991) The significance of the local varieties has been felt, as they are adapted to local environments, agricultural practices and taste of the inhabitants. It is needless to emphasize the use of these genotypes for coping with future climatic changes or outbreak of new diseases and pests. Traditional sweet gourd cultivars are being replaced by more profitable crops in some areas and some landraces are under threat of extinction. It is, therefore, necessary to urgently collect and preserve landraces before some of them are being lost. Among the cultivated varieties of sweet gourd, a wide range of variability exists which can be exploited for its improvement but information regarding sweet gourd genotypes are scarce in scientific literature. Hence, the genetic information on yield and yield contributing characters need to be properly assessed for its improvement. Therefore, the present experiment was conducted to evaluate the field performances and genetic variability of 43 sweet gourd accessions.

\section{Materials and Methods}

The experiment was conducted at the field and laboratory of "Collection, Evaluation, Conservation and Utilization of Landraces and Wild relatives of Some Important Vegetables and Fruits in Bangladesh (CVFB)" project, Department of Horticulture, Bangladesh Agricultural University, Mymensingh during the period from October 2003, to April, 2005. Forty three local sweet gourd genotypes were included in this study. The materials were collected by 'CVFB' project from different parts of Bangladesh which have been described previously (Nahar et al., 2005). The experiment was conducted to evaluate the variability, character association and field performance and genetic divergence of 43 sweet gourd accessions. Each sweet gourd accession was considered as an individual treatment of the experiment. Therefore, there were 43 treatments in this experiment. The sources of the sweet gourd accessions have described previously (Nahar et al., 2005). The experiment was laid out in randomized complete block design with three replications. One accession represented one treatment and two plants in an accession considered one replication. The unit plot was $12 \mathrm{~m}^{2}$ maintaining a distance of $0.5 \mathrm{~m}$ between the plots. Treatments were randomly assigned to different plots of each block separately. The organic and inorganic fertilizers were applied at the rate of 15 ton cowdung, $12 \mathrm{~kg}$ triple super phosphate (TSP), $150 \mathrm{~kg}$ urea and $100 \mathrm{~kg}$ muriate of potash (MoP) per hectare, respectively (BARC, 1997). Fifty percent cowdung was applied at the time of final land preparation. The remaining cowdung, entire quantity of TSP and half of each urea and MoP were applied as basal dose during pit preparation. The rest of urea and MoP were top dressed in two installments at 30 and 50 days after transplanting. Three plants were selected at random from each plot for recording data. Data on different parameters were collected at vegetative and reproductive stages, and on fruit characters as well. The significance of different among the means was evaluated by least significant difference (LSD) test for interpretation of the result (Gomez and Gomez, 1984).

\section{Results and Discussion}

\section{Variability and characterization of vegetative characters among 43 sweet gourd accessions}

Results on variability and character association of different vegetative characters of 43 sweet gourd accessions have presented in Table 01 and Table 02. 
Vine length: The analysis of variance indicated the existence of sufficient genetic variability among the 43 accessions for all the vegetative characters (Table 01 and Table 02). Data on vine length were recorded three times, first at 30 day after dibbling (DAD), second at 60 day after DAD and at final harvest. From the average performance, it was revealed that vine length was not equal in all the accessions and varied significantly (Table 01). At 30 and 60 DAD, the longest $(36.92$ and $456.66 \mathrm{~cm}$, respectively) vine was recorded in CM142 and the shortest (20.21 and $175.00 \mathrm{~cm}$, respectively) vine was recorded in CM135 (Table 01). The maximum vine length $(590 \mathrm{~cm})$ at final harvest was found in CM136 (Table 01) which was statistically similar to CM134, CM142 and CM143 while the minimum vine length was recorded in CM145 followed by CM173 and CM156. Rana et al. (1986) reported a wide range of variability among the sweet gourd accessions at harvest whereas Saha et al. (1992) did not find any significant variation for vine length among the sweet gourd accessions.

Table 01. Performance of 43 sweet gourd accessions for different vegetative characters

\begin{tabular}{|c|c|c|c|c|c|c|}
\hline \multirow{2}{*}{ Acc. No. } & \multicolumn{3}{|c|}{ Vine length $(\mathrm{cm})$ at } & \multirow{2}{*}{$\begin{array}{l}\text { Leaf length } \\
(\mathrm{cm})\end{array}$} & \multirow{2}{*}{$\begin{array}{c}\text { Leaf } \\
\text { breadth }(\mathrm{cm})\end{array}$} & \multirow{2}{*}{$\begin{array}{l}\text { No. of primary } \\
\text { branches/plant }\end{array}$} \\
\hline & $30 \mathrm{DAD}$ & $60 \mathrm{DAD}$ & Final harvest & & & \\
\hline CM131 & 28.96 & 340.00 & 396.66 & 20.33 & 27.67 & 15.17 \\
\hline CM132 & 34.44 & 390.00 & 444.33 & 27.00 & 30.33 & 16.79 \\
\hline CM133 & 28.92 & 345.00 & 415.00 & 22.33 & 28.00 & 16.85 \\
\hline CM134 & 29.84 & 453.33 & 543.33 & 18.67 & 26.00 & 12.86 \\
\hline CM135 & 20.21 & 175.00 & 206.67 & 23.00 & 25.00 & 11.77 \\
\hline CM136 & 29.90 & 422.00 & 590.00 & 23.00 & 25.33 & 14.00 \\
\hline CM137 & 23.40 & 275.00 & 411.00 & 22.00 & 27.33 & 15.13 \\
\hline CM138 & 28.57 & 374.33 & 502.33 & 20.67 & 26.33 & 11.67 \\
\hline CM139 & 25.97 & 325.00 & 403.33 & 23.67 & 24.67 & 10.33 \\
\hline CM140 & 28.39 & 341.67 & 500.00 & 23.33 & 26.00 & 12.52 \\
\hline CM141 & 35.84 & 440.00 & 502.67 & 22.67 & 26.67 & 13.11 \\
\hline CM142 & 36.92 & 456.67 & 521.67 & 22.67 & 28.67 & 11.85 \\
\hline CM143 & 33.38 & 421.00 & 512.67 & 19.33 & 22.00 & 12.32 \\
\hline CM144 & 32.02 & 371.67 & 488.33 & 19.67 & 25.00 & 11.81 \\
\hline CM145 & 29.32 & 343.33 & 404.66 & 19.67 & 23.00 & 12.18 \\
\hline CM146 & 29.11 & 333.33 & 450.00 & 22.33 & 27.67 & 14.33 \\
\hline CM147 & 36.91 & 418.33 & 470.00 & 21.67 & 24.67 & 11.79 \\
\hline CM148 & 34.73 & 448.67 & 455.00 & 16.33 & 20.67 & 9.66 \\
\hline CM149 & 28.26 & 336.67 & 484.33 & 19.33 & 24.33 & 8.59 \\
\hline CM150 & 28.19 & 361.00 & 420.00 & 25.00 & 28.00 & 9.86 \\
\hline CM151 & 27.39 & 344.00 & 391.00 & 18.33 & 23.67 & 10.00 \\
\hline CM152 & 29.05 & 346.67 & 456.00 & 21.33 & 27.00 & 11.19 \\
\hline CM153 & 34.02 & 444.33 & 456.33 & 19.67 & 21.67 & 15.68 \\
\hline CM154 & 28.36 & 394.33 & 482.00 & 20.00 & 23.33 & 15.77 \\
\hline CM155 & 26.72 & 381.67 & 422.67 & 20.00 & 25.00 & 12.61 \\
\hline CM156 & 23.06 & 291.67 & 327.67 & 18.00 & 18.67 & 10.19 \\
\hline CM157 & 28.23 & 446.67 & 457.67 & 19.33 & 22.33 & 10.69 \\
\hline CM158 & 28.26 & 333.33 & 459.33 & 20.67 & 25.67 & 10.50 \\
\hline CM159 & 25.98 & 345.00 & 420.67 & 20.33 & 23.67 & 12.97 \\
\hline CM160 & 28.87 & 321.00 & 395.00 & 16.67 & 20.00 & 13.83 \\
\hline CM161 & 29.44 & 383.67 & 429.00 & 16.33 & 18.67 & 12.49 \\
\hline CM162 & 27.50 & 329.00 & 433.33 & 15.00 & 17.67 & 12.00 \\
\hline CM163 & 30.53 & 412.67 & 452.67 & 17.33 & 22.33 & 13.87 \\
\hline CM164 & 32.43 & 437.67 & 490.00 & 17.33 & 21.00 & 14.84 \\
\hline CM165 & 29.89 & 381.00 & 380.00 & 19.67 & 17.33 & 13.85 \\
\hline CM166 & 28.85 & 360.00 & 369.00 & 21.67 & 21.00 & 13.00 \\
\hline CM167 & 28.11 & 342.67 & 360.67 & 20.00 & 24.00 & 13.51 \\
\hline
\end{tabular}


J. Sci. Technol. Environ. Inform. 04(02): 301-312 | Nahar et al. (2016)

EISSN: 2409-7632, www.journalbinet.com

DOI: $10.18801 /$ jstei.040216.33

\begin{tabular}{lcccccc}
\hline \multirow{2}{*}{ Acc. No. } & \multicolumn{3}{c}{ Vine length $(\mathrm{cm})$ at } & Leaf length & $\begin{array}{c}\text { Leaf } \\
(\mathrm{cm})\end{array}$ & $\begin{array}{c}\text { No. of primary } \\
\text { breadth }(\mathrm{cm})\end{array}$ \\
\cline { 2 - 4 } branches/plant
\end{tabular}

Estimation of genotypic and phenotypic variances was fairly high for vine length at 60 DAD and at final harvest but comparatively lower at 30 DAD (Table 02). Genotypic coefficient of variation was also lower than the corresponding phenotypic one, which indicated the larger influence of environment. There were also considerable differences between genotypic and phenotypic coefficient of variation. Comparatively low difference between GCV and PCV (16.04\% and 16.10\%) was exploited by vine length at final harvest (Table 02). Rahman et al. (1986) also observed moderate value of GCV and PCV (17.44 and 24.08) for vine length in bottle gourd whereas Rana et al. (1986) observed high value in pumpkin. Low values of GCV and PCV indicated low genetic variability within the accessions for vine length. Heritability was found high in case of vine length $(75.06 \%$ at $30 \mathrm{DAD}, 94.03 \%$ at $60 \mathrm{DAD}$ and $99.21 \%$ at final harvest) (Table 02). The results of the present experiment support the findings of Islam et al. (1993). They found high heritability (94.64\%) for vine length in cucumber.

Table 02. Estimates of genetic parameters for different vegetative characters in sweet gourd

\begin{tabular}{|c|c|c|c|c|c|c|c|c|}
\hline \multirow[t]{2}{*}{ Characters } & \multirow{2}{*}{$\begin{array}{l}\text { Genotypic } \\
\text { variance }\end{array}$} & \multirow{2}{*}{$\begin{array}{l}\text { Phenotypic } \\
\text { variance }\end{array}$} & \multicolumn{2}{|c|}{$\begin{array}{l}\text { Co-efficient of } \\
\text { variation } \%\end{array}$} & \multirow[t]{2}{*}{ Range } & \multirow[t]{2}{*}{ Mean SE } & \multirow[t]{2}{*}{ Heritability } & \multirow{2}{*}{$\begin{array}{l}\text { CV } \\
(\%)\end{array}$} \\
\hline & & & GCV & PCV & & & & \\
\hline $\begin{array}{l}\text { Vine length }(\mathrm{cm}) \\
\text { after } 30 \text { DAD }\end{array}$ & 13.09 & 17.44 & 12.48 & 14.41 & $\begin{array}{l}20.21- \\
36.92\end{array}$ & 28.981 .70 & 75.06 & 7.19 \\
\hline $\begin{array}{l}\text { Vine length }(\mathrm{cm}) \\
\text { after } 60 \text { DAD }\end{array}$ & 3466.77 & 3676.13 & 16.18 & 16.66 & $\begin{array}{l}175.00- \\
456.66\end{array}$ & $\begin{array}{l}363.97 \\
11.80\end{array}$ & 94.30 & 3.98 \\
\hline $\begin{array}{l}\text { Vine length }(\mathrm{cm}) \\
\text { at final harvest }\end{array}$ & 4834.86 & 4873.17 & 16.04 & 16.10 & $\begin{array}{l}206.66- \\
590.00\end{array}$ & 433.635 .05 & 99.21 & 1.43 \\
\hline Leaf length $(\mathrm{cm})$ & 5.88 & 10.97 & 12.2 & 16.66 & $\begin{array}{l}15.00- \\
27.00\end{array}$ & 19.881 .83 & 53.60 & 11.35 \\
\hline $\begin{array}{l}\text { Leaf breadth } \\
(\mathrm{cm})\end{array}$ & 6.29 & 18.31 & 10.6 & 18.08 & $\begin{array}{l}17.33- \\
30.33\end{array}$ & 23.672 .83 & 34.35 & 14.64 \\
\hline $\begin{array}{l}\text { No. of primary } \\
\text { branches }\end{array}$ & 2.82 & 5.11 & 13.33 & 17.94 & $8.58-16.84$ & 12.591 .23 & 55.19 & 12 \\
\hline
\end{tabular}

Leaf size: It was observed that leaf length varied significantly among the accessions and ranging from 15.00 to $27.00 \mathrm{~cm}$ with the mean value of $19.88 \mathrm{~cm}$. The longest length of leaf $(27.00 \mathrm{~cm})$ was found in CM132 followed by CM139, CM140 and CM150 (23.66, 23.33 and $25.00 \mathrm{~cm}$, respectively) while the lowest length of leaf $(15.00 \mathrm{~cm})$ was found in CM162 and CM171 followed by CM169, CM170 $(16.00 \mathrm{~cm}$ and $15.66 \mathrm{~cm}$, respectively)(Table 01). Considerable differences were found between genotypic (5.88) and phenotypic (10.97) variances. Genotypic (12.2\%) and phenotypic (16.66\%) coefficient of variations indicated environmental effect upon the expression of the character. Moderate heritability (53.60\%) was found for leaf length (Table 02). The highest breadth of leaf $(30.33 \mathrm{~cm})$ was found in CM132, and the shortest breadth of leaf $(17.33 \mathrm{~cm})$ was observed in CM165. Thus the range lies between 17.33$30.33 \mathrm{~cm}$ with mean value of 23.67 indicating that large variability existed in leaf breadth (Table 01). Medium range of genotypic (6.29) and phenotypic (18.31) variance as well as GCV (10.6\%) and PCV $(18.08 \%)$ indicated medium genetic variability within the accessions for this trait. Leaf breadth showed 
moderately low heritability (34.35\%) (Table 02). Vashistha et al. (1983) reported high heritability in water melon.

Number of primary branches: Significant difference was observed for number of primary branches among the accessions. The highest number of primary branches (16.84) was observed in CM133 followed by CM132, CM153, CM154 and CM164. The lowest number of primary branches (8.58) were found in CM149 which was statistically similar with CM150, CM151, CM148 and CM156. The range lies between (8.58 - 16.84) with the average mean value of 12.59 that indicated moderate variability among the accessions for this trait (Table 01). Genotypic (2.82) and phenotypic (5.11) variances and its coefficient of variations (13.33 and $17.94 \%$, respectively) were observed (Table 02). The difference between GCV and PCV is quiet broader which indicated moderate environmental effect on the expression for this trait. Similar results was found by Rana et al. (1986) in pumpkin. Also moderate heritability (55.19\%) was observed for this trait (Table 02).

\section{Variability and characterization of reproductive characters among 43 sweet gourd accessions}

Male and female flowers and sex ratio per plant: The range of variation was recorded in sex ratio (male: female) (5.03 -11.60) followed by female (4.66-11.66) and male flowers (51.00-91.66) per plant with the mean value of 7.71, 8.93 and 60.50, respectively among the reproductive characters (Table 03). These findings are in agreement with those reported by Chigwe (1991) in sweet gourd. Characters which showed high range of variation should be given priority in the selection (Vijay, 1987). From the average performance, the accession CM148 produced the maximum number of male flowers per plant (91.66) whileCM151 produced the lowest number of male flowers per plant (51.00) (Table 03). The highest number of female flowers per plant (11.66) was recorded in CM143 and CM159. The lowest number of female flowers per plant (4.66) was found in CM154 which was statistically similar to CM136, CM152, CM155, CM156, CM149 and CM158 (Table 03).

The highest sex ratio (11.60) was recorded in CM147 and the lowest sex ratio (5.03) was observed in CM165 with mean value of 7.71 (Table 03). In cucurbits sex ratio varies from 15:1 to 30:1, the former condition is advantageous and economical because it results in greater number of pistillate flowers per plant consequently higher fruit set and yield (Bose and Som, 1986). Estimated genotypic (129.640) and phenotypic (134.98) variances were fairly high for male flowers per plant. Female flowers/plant and sex ratio showed moderately higher phenotypic variances 5.36 and 3.81 than genotypic variances 3.92 and 1.99. The highest GCV (22.17\%) was found in female flowers/plant followed by male flowers per plant (17.38\%) and sex ratio (18.30) (Table 04). This high GCV can be exploited by appropriate selection. Arora et al. (1983) also reported high GCV value for sex ratio (64.98\%) in sponge gourd.

The phenotypic coefficient of variation was found $17.74,25.93$ and 25.32 for male flowers per plant, female flowers per plant and in sex ratio, respectively which indicated that these characters are influenced by environment. Calculated value of heritability was $96.04 \%, 73.13 \%$ and $52.33 \%$ for male flower per plant, female flower per plant and sex ratio, respectively (Table 04). Arora et al. (1983) and Srivastava and Srivastava (1976) also found high heritability as well as high genetic advance for sex ratio (83.83\% and 122.58$)$ and female flowers per plant $(98.84 \%$ and 40.49$)$, respectively in sponge and bitter gourd which were in line with the present findings. On the other hand, Srivastava and Srivastava (1976) reported low values (49.93\% and 16.73) for male flowers per plant in bitter gourd.

Days to first male flowering: Among 43 accessions CM131 showed early flowering. It took the shortest time (54.21 days) to flowering which was statistically similar to CM137, CM144, CM152, CM155, CM156, CM159, CM161 and CM170. On the other hand, CM140 showed the highest number of days (64.50) to male flowering, which was statistically similar with CM135, CM139, CM145, CM148, CM149 and CM150. Thus the range for this trait lies between 54.21-64.50 with the mean value (58.94) (Table 03). Differences between genotypic (6.07) and phenotypic (7.75) variances as well as genotypic $(4.18 \%)$ and phenotypic (4.72\%) coefficient of variation was low indicating less environmental effect upon the expression of this trait (Table 04). Abusaleha and Dutta (1990) found high genotypic and 
J. Sci. Technol. Environ. Inform. 04(02): 301-312 | Nahar et al. (2016)

EISSN: 2409-7632, www.journalbinet.com

DOI: $10.18801 /$ jstei.040216.33

phenotypic (33.22 and 33.88) value for days to male flowering in cucumber. Calculated value for heritability was (78.32\%) (Table 04). The results of this experiment are in agreement with the findings of Islam et al. (1993).

Table 03. Performance of 43 sweet gourd accessions for different reproductive characters

\begin{tabular}{|c|c|c|c|c|c|}
\hline Acc. No. & $\begin{array}{l}\text { No. of male } \\
\text { flowers/plant }\end{array}$ & $\begin{array}{l}\text { No. of female } \\
\text { flowers/plant }\end{array}$ & $\begin{array}{l}\text { Sex ratio } \\
\text { (male: female) }\end{array}$ & $\begin{array}{l}\text { Days to } 1^{\text {st }} \\
\text { male flower }\end{array}$ & $\begin{array}{l}\text { Days to } 1^{\text {st }} \\
\text { female flower }\end{array}$ \\
\hline CM131 & 52.33 & 8.00 & 6.29 & 54.21 & 59.59 \\
\hline CM132 & 65.67 & 10.67 & 6.35 & 57.45 & 63.03 \\
\hline CM133 & 73.67 & 10.00 & 7.71 & 58.58 & 65.15 \\
\hline CM134 & 68.33 & 8.00 & 8.66 & 61.92 & 68.33 \\
\hline CM135 & 81.33 & 10.33 & 8.68 & 63.18 & 65.67 \\
\hline CM136 & 58.67 & 5.67 & 9.59 & 57.17 & 59.98 \\
\hline CM137 & 69.33 & 9.00 & 7.62 & 56.92 & 59.40 \\
\hline CM138 & 56.00 & 7.67 & 7.88 & 57.22 & 62.26 \\
\hline CM139 & 80.33 & 10.33 & 7.84 & 61.53 & 65.82 \\
\hline CM140 & 72.67 & 11.00 & 6.64 & 64.50 & 65.38 \\
\hline CM141 & 66.67 & 7.67 & 8.71 & 57.52 & 60.79 \\
\hline CM142 & 51.00 & 7.33 & 7.06 & 58.69 & 62.90 \\
\hline CM143 & 89.00 & 11.67 & 7.72 & 60.06 & 62.96 \\
\hline CM144 & 75.67 & 11.00 & 6.90 & 56.86 & 62.60 \\
\hline CM145 & 67.67 & 8.00 & 8.56 & 63.40 & 64.43 \\
\hline CM146 & 73.00 & 10.33 & 7.17 & 59.19 & 62.52 \\
\hline CM147 & 68.67 & 6.00 & 11.60 & 62.17 & 64.39 \\
\hline CM148 & 91.67 & 10.00 & 9.40 & 62.87 & 65.92 \\
\hline CM149 & 67.67 & 6.33 & 10.72 & 63.52 & 65.71 \\
\hline CM150 & 73.67 & 8.33 & 8.05 & 63.46 & 64.32 \\
\hline CM151 & 80.00 & 9.00 & 8.93 & 57.14 & 58.96 \\
\hline CM152 & 57.67 & 5.33 & 10.87 & 55.69 & 58.88 \\
\hline CM153 & 60.00 & 8.33 & 6.86 & 57.79 & 59.42 \\
\hline CM154 & 51.67 & 4.67 & 10.65 & 58.35 & 59.92 \\
\hline CM155 & 54.00 & 5.33 & 9.53 & 56.45 & 57.16 \\
\hline CM156 & 42.67 & 5.67 & 7.80 & 55.68 & 57.58 \\
\hline CM157 & 48.00 & 9.00 & 5.86 & 57.64 & 59.38 \\
\hline CM158 & 45.00 & 6.67 & 5.75 & 57.62 & 58.32 \\
\hline CM159 & 57.67 & 11.67 & 5.55 & 56.95 & 57.79 \\
\hline CM160 & 54.67 & 8.00 & 7.93 & 56.89 & 58.39 \\
\hline CM161 & 55.33 & 6.00 & 8.90 & 56.22 & 58.65 \\
\hline CM162 & 72.00 & 8.00 & 10.06 & 57.35 & 61.31 \\
\hline CM163 & 82.33 & 11.00 & 7.53 & 60.41 & 63.27 \\
\hline CM164 & 70.67 & 11.67 & 6.15 & 61.92 & 62.61 \\
\hline CM165 & 53.33 & 10.67 & 5.03 & 59.78 & 59.81 \\
\hline CM166 & 63.33 & 11.00 & 5.78 & 57.62 & 58.86 \\
\hline CM167 & 72.33 & 11.00 & 6.60 & 57.46 & 60.91 \\
\hline CM168 & 70.67 & 11.67 & 6.23 & 60.68 & 62.11 \\
\hline CM169 & 74.00 & 11.00 & 6.93 & 58.82 & 58.06 \\
\hline CM170 & 63.33 & 10.00 & 6.80 & 56.19 & 59.82 \\
\hline CM171 & 65.00 & 9.00 & 6.44 & 60.03 & 63.04 \\
\hline CM172 & 56.00 & 11.00 & 5.63 & 60.03 & 61.75 \\
\hline CM173 & 64.00 & 11.00 & 6.66 & 57.65 & 59.06 \\
\hline LSD (0.01) & 4.97 & 2.58 & 2.91 & 2.79 & 4.41 \\
\hline (0.05) & 3.75 & 1.95 & 2.19 & 2.10 & 3.33 \\
\hline
\end{tabular}


J. Sci. Technol. Environ. Inform. 04(02): 301-312 | Nahar et al. (2016)

EISSN: 2409-7632, www.journalbinet.com

DOI: $10.18801 /$ jstei.040216.33

Table 04. Estimate of genetic parameters for different reproductive characters in sweet gourd

\begin{tabular}{|c|c|c|c|c|c|c|c|c|}
\hline \multirow[t]{2}{*}{ Characters } & \multirow{2}{*}{$\begin{array}{l}\text { Genotypic } \\
\text { variance }\end{array}$} & \multirow{2}{*}{$\begin{array}{l}\text { Phenotypic } \\
\text { variance }\end{array}$} & \multicolumn{2}{|c|}{$\begin{array}{l}\text { Co-efficient of } \\
\text { variation } \%\end{array}$} & \multirow[t]{2}{*}{ Range } & \multirow[t]{2}{*}{ Mean SE } & \multirow{2}{*}{$\begin{array}{l}\text { Heritability } \\
(\%)\end{array}$} & \multirow{2}{*}{$\begin{array}{l}\mathrm{CV} \\
(\%)\end{array}$} \\
\hline & & & GCV & PCV & & & & \\
\hline $\begin{array}{l}\text { Male } \\
\text { flowers/plant }\end{array}$ & 129.64 & 134.98 & 17.38 & 17.74 & $\begin{array}{l}51.00- \\
91.66\end{array}$ & $\begin{array}{l}60.50 \\
1.89\end{array}$ & 96.04 & 3.53 \\
\hline $\begin{array}{l}\text { Female } \\
\text { flowers/plant }\end{array}$ & 3.92 & 5.36 & 22.17 & 25.93 & $\begin{array}{l}4.66- \\
11.66\end{array}$ & 8.930 .98 & 73.13 & 13.44 \\
\hline $\begin{array}{l}\text { Days to } 1^{\text {st }} \\
\text { male flower }\end{array}$ & 6.07 & 7.75 & 4.18 & 4.72 & $\begin{array}{l}54.21- \\
64.50\end{array}$ & $\begin{array}{l}58.94- \\
1.06\end{array}$ & 78.32 & 2.20 \\
\hline $\begin{array}{l}\text { Days to } 1^{\text {st }} \\
\text { female flower }\end{array}$ & 6.5 & 10.70 & 4.14 & 5.32 & $\begin{array}{l}57.16- \\
68.33\end{array}$ & 61.541 .67 & 60.75 & 3.33 \\
\hline Sex ratio & 1.99 & 3.81 & 18.30 & 25.32 & $\begin{array}{l}5.03- \\
11.60\end{array}$ & 7.711 .10 & 52.23 & 10.54 \\
\hline
\end{tabular}

Days to first male flowering: Among 43 accessions CM131 showed early flowering. It took the shortest time (54.21 days) to flowering which was statistically similar to CM137, CM144, CM152, CM155, CM156, CM159, CM161 and CM170. On the other hand, CM140 showed the highest number of days (64.50) to male flowering, which was statistically similar with CM135, CM139, CM145, CM148, CM149 and CM150. Thus the range for this trait lies between 54.21-64.50 with the mean value (58.94) (Table 03). Differences between genotypic (6.07) and phenotypic (7.75) variances as well as genotypic $(4.18 \%)$ and phenotypic (4.72\%) coefficient of variation was low indicating less environmental effect upon the expression of this trait (Table 04). Abusaleha and Dutta (1990) found high genotypic and phenotypic (33.22 and 33.88) value for days to male flowering in cucumber. Calculated value for heritability was (78.32\%) (Table 04). The results of this experiment are in agreement with the findings of Islam et al. (1993).

Days to first female flower: This is an important character that influences the yield. Accession CM134 required maximum days to first female flowering (68.33 days) which was followed by CM133, CM135, CM147, CM148 and CM149 minimum days required for first female flowering was (57.16 days) in CM131 followed by CM136, CM137, CM155, CM156 and CM159 (Table 03). Among 43 accessions the phenotypic variance (10.70) was quite closer with the genotypic variance (6.5). Also narrow difference was observed between PCV (5.32\%) and GCV (4.14\%) which indicated that this trait is genetically controlled. Estimated heritability was found $60.75 \%$ (Table 04). So the plant breeder should select this trait for breeding parameter. This result was similar with the findings of Islam et al. (1993) but dissimilar with Abusaleha and Dutta (1990).

\section{Variability and characterization of yield and yield contributing characters among 43 sweet gourd accessions}

Fruit length and diameter: The analysis of variance indicated a high degree of variation among the accessions for all the yield contributing characters. Among the accessions studied the longest fruit $(50.33 \mathrm{~cm})$ was recorded in CM154 which was followed by CM148 and CM162 with the mean value $34.77 \mathrm{~cm}$. While the shortest fruit was found in CM173 $(22.00 \mathrm{~cm})$ followed by CM131 and CM132. The highest fruit diameter $(82.00 \mathrm{~cm})$ was recorded in CM160. The lowest fruit diameter was recorded in CM173 $(45.00 \mathrm{~cm})$ and followed by CM131 (Table 05).

A high difference between genotypic (49.36 and 29.14) and phenotypic (88.20 and 88.20) variances were found for fruit length and diameter, respectively. Comparatively moderate difference between GCV (15.53) and PCV (27.01) was found for fruit length whereas smaller difference between GCV (10.74) and PCV (14.36) were recorded for fruit diameter. Sharma et al. (2000) observed similar result in cucumber. For fruit length and diameter heritability was found $33.04 \%$ and $55.96 \%$, respectively (Table 06). 
J. Sci. Technol. Environ. Inform. 04(02): 301-312 | Nahar et al. (2016)

EISSN: 2409-7632, www.journalbinet.com

DOI: $10.18801 /$ jstei.040216.33

Table 05. Performance of 43 sweet gourd accessions for different yield contributing characters

\begin{tabular}{|c|c|c|c|c|c|c|}
\hline Acc. No. & $\begin{array}{l}\text { Fruit length } \\
(\mathrm{cm})\end{array}$ & $\begin{array}{l}\text { Fruit } \\
\text { Diameter } \\
(\mathrm{cm})\end{array}$ & $\begin{array}{l}\text { Flesh } \\
\text { thickness } \\
(\mathrm{cm})\end{array}$ & $\begin{array}{l}\text { Fruit cavity } \\
\text { Length }(\mathrm{cm})\end{array}$ & $\begin{array}{l}\text { Fruit cavity } \\
\text { breadth }(\mathrm{cm})\end{array}$ & $\begin{array}{l}\text { Dry weight of } \\
100 \mathrm{~g} \text { flesh }\end{array}$ \\
\hline CM131 & 23.50 & 48.00 & 4.30 & 9.40 & 10.00 & 10.47 \\
\hline CM132 & 23.50 & 52.00 & 2.30 & 5.47 & 9.00 & 5.01 \\
\hline CM133 & 28.00 & 67.00 & 3.33 & 9.03 & 13.37 & 5.40 \\
\hline CM134 & 34.27 & 69.00 & 3.90 & 10.13 & 13.23 & 4.87 \\
\hline CM135 & 33.00 & 61.33 & 2.93 & 17.03 & 10.20 & 5.37 \\
\hline CM136 & 36.30 & 61.67 & 3.50 & 19.03 & 12.20 & 6.32 \\
\hline CM137 & 43.00 & 58.67 & 3.00 & 19.03 & 10.40 & 4.00 \\
\hline CM138 & 35.00 & 65.33 & 4.03 & 14.10 & 13.33 & 5.95 \\
\hline CM139 & 38.00 & 71.00 & 2.97 & 7.40 & 11.40 & 8.37 \\
\hline CM140 & 37.67 & 64.00 & 4.40 & 19.20 & 15.37 & 4.57 \\
\hline CM141 & 37.33 & 64.00 & 2.97 & 19.27 & 15.13 & 7.77 \\
\hline CM142 & 28.00 & 62.33 & 3.40 & 21.93 & 9.40 & 5.20 \\
\hline CM143 & 29.00 & 69.67 & 3.07 & 14.37 & 10.37 & 3.37 \\
\hline CM144 & 35.00 & 62.67 & 4.10 & 15.07 & 12.17 & 5.53 \\
\hline CM145 & 34.67 & 69.00 & 3.33 & 10.40 & 12.40 & 6.51 \\
\hline CM146 & 35.33 & 73.00 & 1.37 & 15.40 & 5.20 & 7.55 \\
\hline CM147 & 38.67 & 64.33 & 3.10 & 18.30 & 11.33 & 4.83 \\
\hline CM148 & 43.67 & 66.67 & 3.17 & 19.03 & 16.30 & 6.47 \\
\hline CM149 & 29.33 & 68.33 & 4.03 & 9.33 & 13.30 & 4.87 \\
\hline CM150 & 36.67 & 67.00 & 5.00 & 20.33 & 11.33 & 4.23 \\
\hline CM151 & 37.33 & 67.67 & 4.03 & 18.03 & 12.97 & 7.77 \\
\hline CM152 & 40.00 & 73.00 & 3.17 & 14.17 & 17.03 & 5.42 \\
\hline CM153 & 33.33 & 75.00 & 4.10 & 7.30 & 14.47 & 4.90 \\
\hline CM154 & 50.33 & 77.00 & 4.40 & 26.03 & 15.90 & 5.90 \\
\hline CM155 & 37.33 & 57.33 & 4.00 & 19.03 & 10.30 & 4.93 \\
\hline CM156 & 32.33 & 57.00 & 3.97 & 13.60 & 14.37 & 6.55 \\
\hline CM157 & 40.67 & 69.67 & 3.73 & 26.03 & 11.40 & 5.01 \\
\hline CM158 & 38.33 & 77.67 & 4.13 & 14.10 & 18.37 & 5.60 \\
\hline CM159 & 32.00 & 52.00 & 2.83 & 13.33 & 13.03 & 4.13 \\
\hline CM160 & 36.00 & 82.00 & 5.03 & 12.30 & 18.13 & 6.24 \\
\hline CM161 & 35.00 & 68.67 & 3.00 & 15.17 & 12.17 & 7.48 \\
\hline CM162 & 41.00 & 60.33 & 2.97 & 22.07 & 11.50 & 8.41 \\
\hline CM163 & 31.33 & 71.00 & 3.47 & 8.47 & 13.17 & 6.47 \\
\hline CM164 & 38.00 & 66.00 & 5.37 & 15.63 & 14.37 & 7.26 \\
\hline CM165 & 35.67 & 72.67 & 4.73 & 12.10 & 15.03 & 5.76 \\
\hline CM166 & 35.00 & 70.67 & 4.23 & 13.90 & 15.03 & 5.73 \\
\hline CM167 & 33.33 & 70.00 & 4.10 & 12.40 & 15.23 & 8.46 \\
\hline CM168 & 36.00 & 59.67 & 4.47 & 10.10 & 15.30 & 6.47 \\
\hline CM169 & 28.33 & 61.67 & 4.43 & 10.10 & 14.40 & 5.45 \\
\hline CM170 & 28.00 & 53.67 & 3.43 & 7.97 & 10.50 & 7.22 \\
\hline CM171 & 37.33 & 73.67 & 4.33 & 20.40 & 15.30 & 5.51 \\
\hline CM172 & 36.67 & 66.00 & 3.00 & 13.23 & 13.10 & 3.21 \\
\hline CM173 & 22.00 & 45.00 & 2.50 & 7.03 & 9.10 & 4.83 \\
\hline LSD (0.01) & 4.27 & 13.41 & 0.25 & 1.96 & 0.39 & 0.15 \\
\hline$(0.05)$ & 3.22 & 10.12 & 0.19 & 1.48 & 0.29 & 0.11 \\
\hline
\end{tabular}


J. Sci. Technol. Environ. Inform. 04(02): 301-312 | Nahar et al. (2016)

EISSN: 2409-7632, www.journalbinet.com

DOI: $10.18801 /$ jstei.040216.33

Table 06. Estimate of genetic parameters for different yield contributing characters in sweet gourd

\begin{tabular}{|c|c|c|c|c|c|c|c|c|}
\hline \multirow[t]{2}{*}{ Characters } & \multirow{2}{*}{$\begin{array}{l}\text { Genotypic } \\
\text { variance }\end{array}$} & \multirow{2}{*}{$\begin{array}{l}\text { Phenotypic } \\
\text { variance }\end{array}$} & \multicolumn{2}{|c|}{$\begin{array}{l}\text { Co-efficient of } \\
\text { variation } \%\end{array}$} & \multirow[t]{2}{*}{ Range } & \multirow[t]{2}{*}{ Mean SE } & \multirow{2}{*}{$\begin{array}{l}\text { Heritability } \\
(\%)\end{array}$} & \multirow{2}{*}{$\begin{array}{l}\mathrm{CV} \\
(\%)\end{array}$} \\
\hline & & & GCV & PCV & & & & \\
\hline $\begin{array}{l}\text { Fruit length } \\
(\mathrm{cm})\end{array}$ & 29.14 & 88.20 & 15.53 & 27.01 & $\begin{array}{l}22.00- \\
50.33\end{array}$ & 34.771 .62 & 33.04 & 5.71 \\
\hline $\begin{array}{l}\text { Fruit diameter } \\
(\mathrm{cm})\end{array}$ & 49.36 & 88.20 & 10.74 & 14.36 & $\begin{array}{l}45.00- \\
82.00\end{array}$ & 65.405 .09 & 55.96 & 9.53 \\
\hline $\begin{array}{l}\text { Fruit weight } \\
\text { (kg) }\end{array}$ & 3.61 & 3.78 & 39.50 & 40.43 & $\begin{array}{l}0.68- \\
10.43\end{array}$ & 4.810 .34 & 97.70 & 8.52 \\
\hline $\begin{array}{l}\text { No. of } \\
\text { fruits/plant }\end{array}$ & 1.84 & 4.05 & 19.72 & 29.25 & $\begin{array}{l}5.00- \\
10.00\end{array}$ & 6.871 .21 & 45.43 & 21.61 \\
\hline $\begin{array}{l}\text { Flesh thickness } \\
\text { (cm) }\end{array}$ & 0.63 & 0.65 & 21.63 & 21.97 & $\begin{array}{l}1.30- \\
5.36\end{array}$ & 3.660 .10 & 96.92 & 3.23 \\
\hline $\begin{array}{l}\text { Dry weight of } \\
100 \mathrm{~g} \text { flesh }\end{array}$ & 2.19 & 2.20 & 24.91 & 24.97 & $4-10.46$ & 5.940 .06 & 99.55 & 1.16 \\
\hline $\begin{array}{l}\text { Yield } \\
\text { (kg/plant) }\end{array}$ & 97.60 & 181.89 & 32.33 & 44.13 & $\begin{array}{l}9.73- \\
57.80\end{array}$ & 30.567 .50 & 53.66 & 30.04 \\
\hline
\end{tabular}

Number of fruits per plant: From Figure 01 it was observed that the maximum number of fruits per plant (10.00) was produced by CM145 which was significantly different from the other accessions. The accession CM143, CM144, CM151 and CM172 also produced higher number of fruits and were statistically alike. The minimum fruit bearing (5.00 per plant) was observed in CM136 and followed by CM159, CM160, CM163 and CM164 (Figure 02). Saha et al. (1992) reported 1.75-4.50 fruits per plant in pumpkin. The comparatively higher degree of GCV and PCV exhibited by fruits per plant $(19.72 \%$ and $29.25 \%$ ) and moderate high heritability (45.43\%) showed for the number of fruits per plant (Table 06).

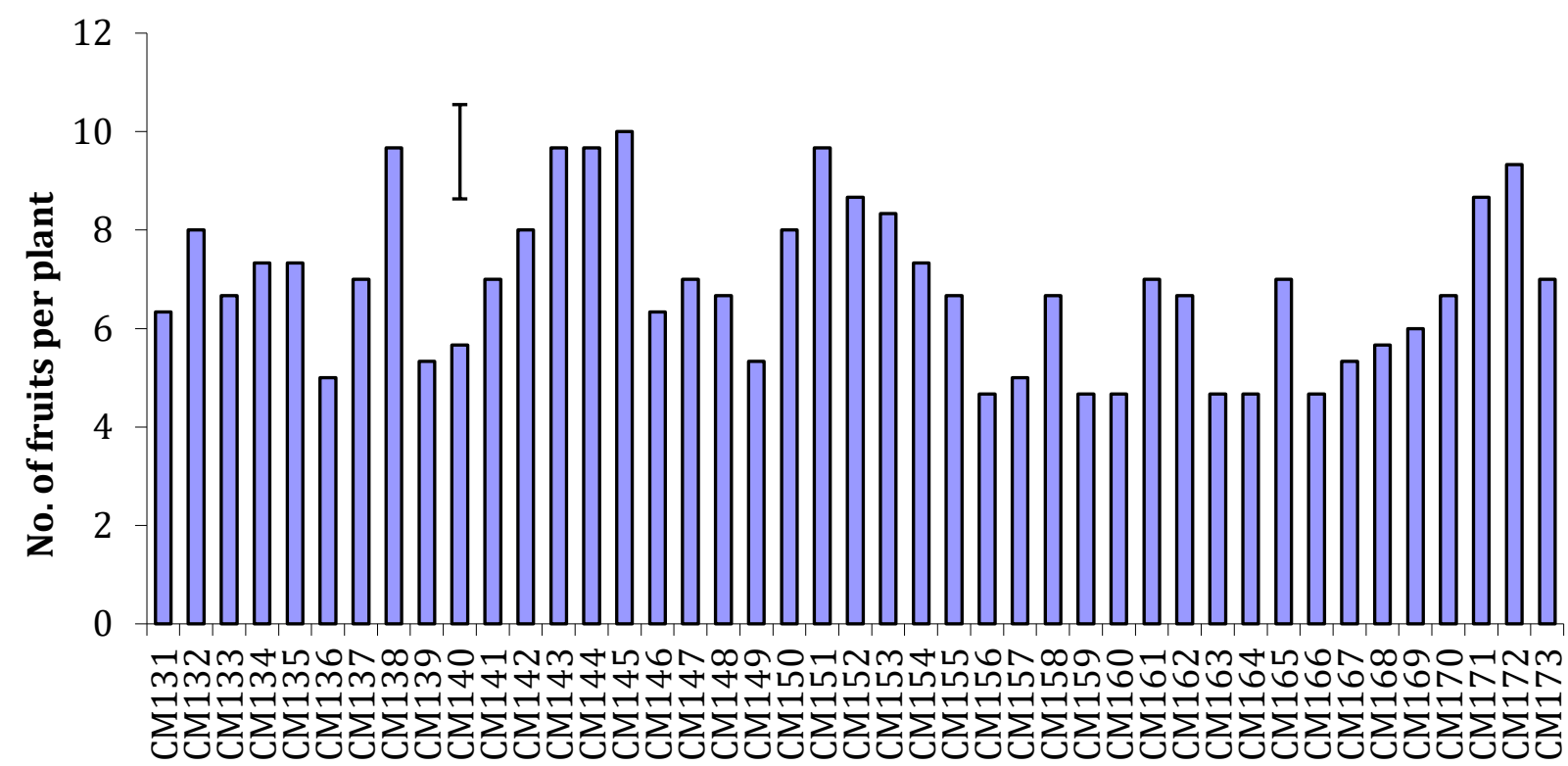

Accession number

Figure 01. Number of fruits per plant of 43 sweet gourd accessions (vertical bar represents LSD at $1 \%$ level of probability).

Fruit weight: The range of fruit weight lies between $(0.68-10.43 \mathrm{~kg})$ with the mean value of $4.81 \mathrm{~kg}$. The fruit weight $(10.43 \mathrm{~kg})$ was maximum in CM154 which significantly differed from all other accessions. The minimum fruit weight $(0.68 \mathrm{~kg})$ was produced by CM173 followed by CM131 and CM132 (Figure 02). The variation in fruit weight was also reported by Doijode and Sulladmath (1986) 
(0.5-4.9 kg), Saha et al. (1992) (2.7 kg) and Gopalakrishnan and Peter (1987) (1.7 kg) in pumpkin. Low GCV $(39.5 \%)$ and PCV (40.43\%) was also observed in fruit weight. Heritability for fruit weight was $(97.70 \%)$ (Table 06).

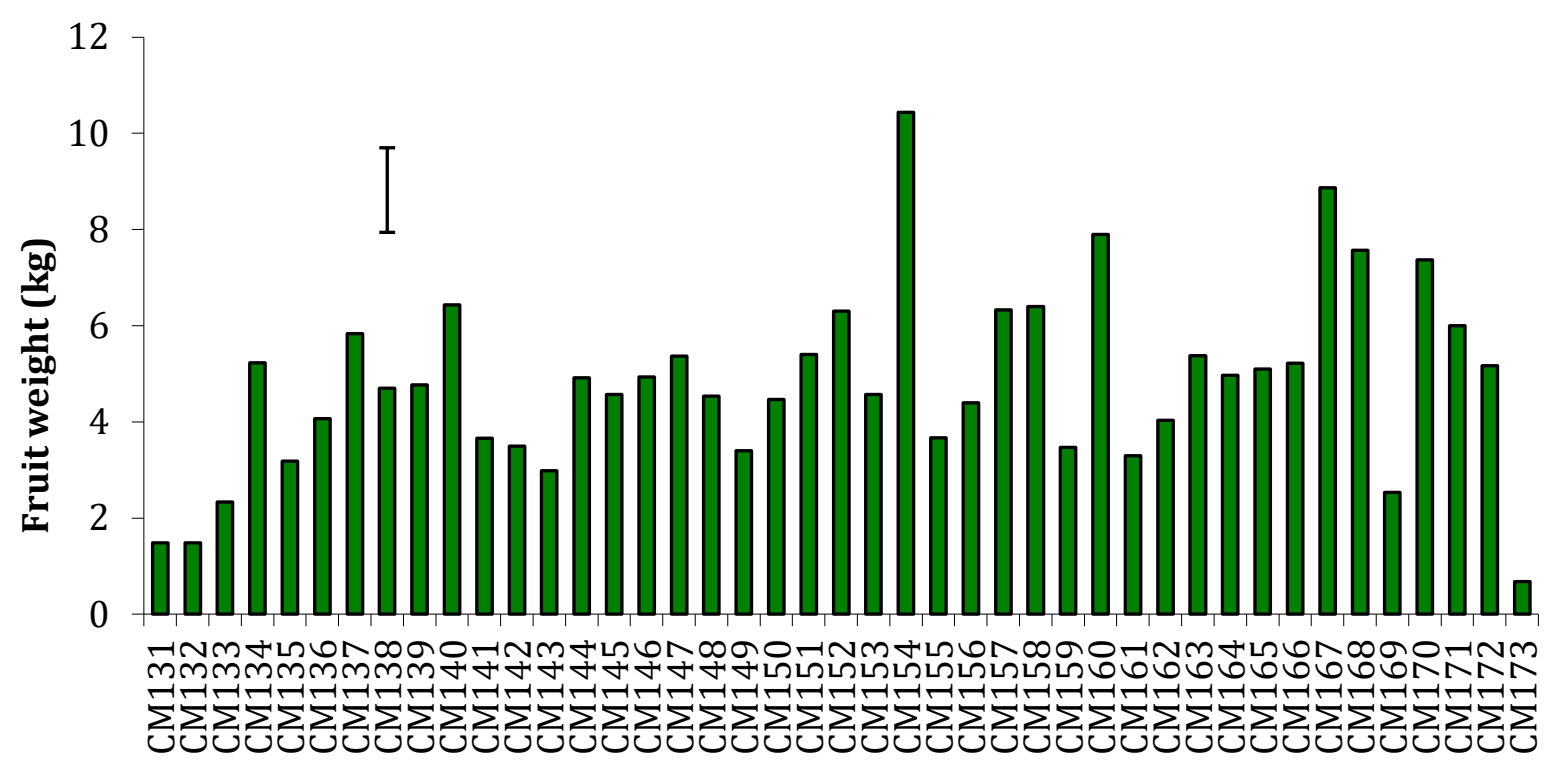

Accession number

Figure 02. Fruit weight of 43 sweet gourd accessions (vertical bar represents LSD at $1 \%$ level of probability).

Dry weight of $100 \mathrm{~g}$ flesh: The fruit dry matter varied from (4.00-10.46 g) with mean value of 5.94 (Table 05). The difference between GCV (24.91\%) and PCV (24.97\%) of this character was narrow confirming the least environmental influence. This trait was highly heritable (99.55\%) (Table 06).

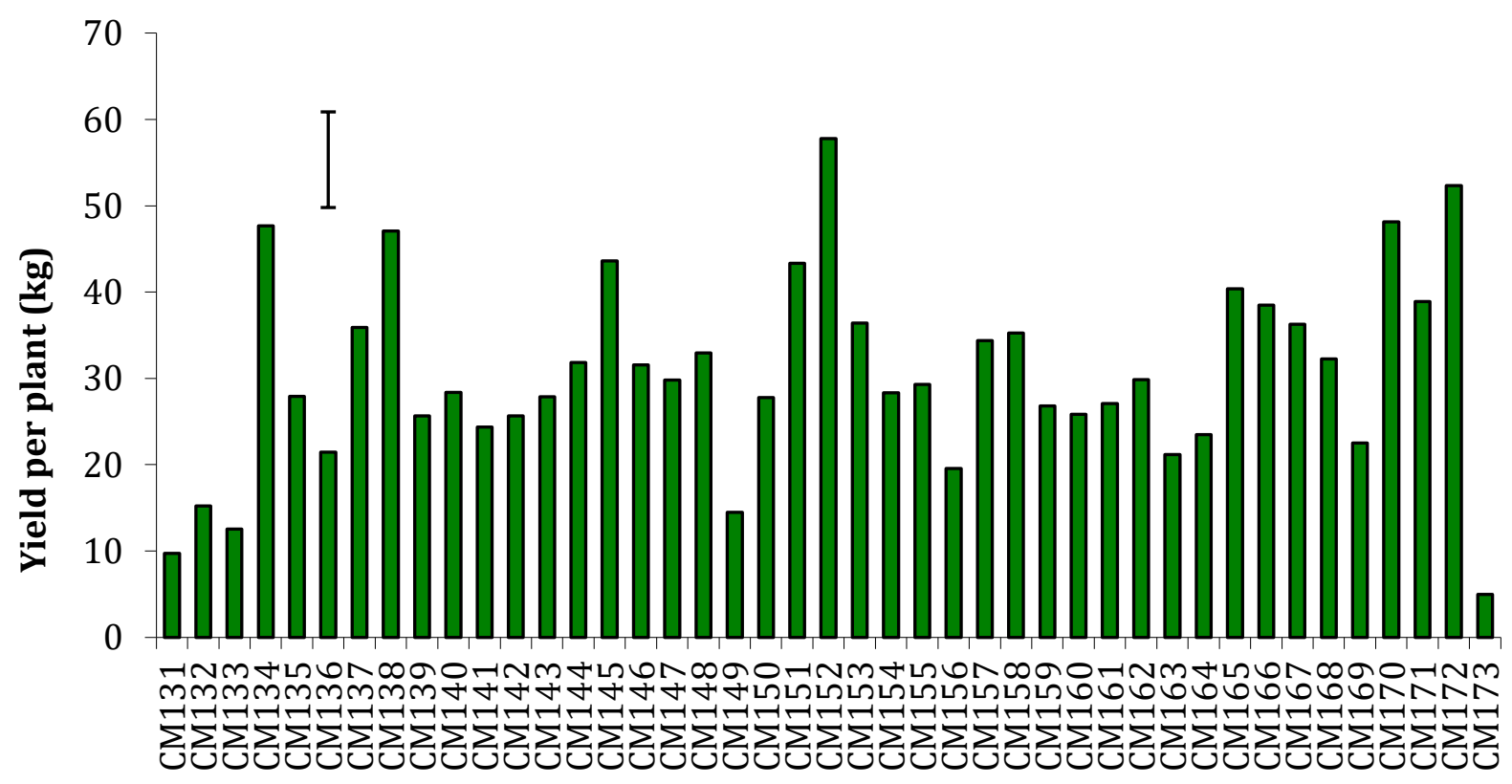

Accession number

Figure 03. Yield per plant of 43 sweet gourd accessions (vertical bar represents LSD at 1\% level of probability). 
Yield per plant: The accession CM152 gave the highest yield per plant (57.80 kg) followed by CM134, CM138 and CM170 (Figure 03). The lowest yield (9.73 kg) was found in CM131 followed by CM173 (Figure 03). Yield per plant showed the mean value $(30.56 \mathrm{~kg}$ ) per plant with high GCV (32.33\%) and PCV (44.13\%). Moderate heritability (53.66\%) was observed for this trait (Table 06). The present findings are in agreement with Saha et al. (1992) and Ahmed (1988). In the present study heritability estimates were high for fruit weight (97.90\%), fruit cavity length $(96.70 \%)$, fruit cavity breadth (99.58\%), flesh thickness (96.92\%), dry weight of $100 \mathrm{~g}$ flesh (99.55\%) and yield (53.66\%) which indicated that these characters were less influenced by environment. High heritability value would be most effective condition for selection. Therefore effective selection could be made for these traits.

\section{Conclusion}

Results revealed that wide variability exists among the sweet gourd accessions used in the present experiment. This variability can be used for selection of superior genotypes for cultivation at farmers' level as well as breeding for developing new varieties of sweet gourd. Selection criteria should include characters such as fruit length, fruit diameter, number of fruits per plant and average fruit weight for the development of high yielding varieties of sweet gourd. Further collection of sweet gourd germplasm should be continued for wider genetic variability and selection of desired traits.

\section{Acknowledgement}

We thank to the United States Department of Agriculture (USDA) for providing financial support for conducting the research.

\section{References}

[1]. Abusaleha \& Dutta, O. P. (1990). Association of yield components in ribbed gourd. Haryana Journal of Horticulture Sciences, 19(3-4), 358-362.

[2]. Ahmed, M. S. (1988). Studies on growth and yield of four promising pumpkin (Cucurbita moschata) lines. Annual Report. Bangladesh Agricultural Research Institute. Joydebpur. p. 284.

[3]. Arora, S. K., Pandita, M. L., Partap, P. S. \& Sidhu, A. S. (1983). Variability and correlation studies in sponge gourd (Luffa cylindrica Roem.). Haryana Agricultural University Journal of Research, 13(1), 146-149.

[4]. BARC (1997). Fertilizer Recommendation Guide. Bangladesh Agricultural Research Council. Farmgate, New Airport Road, Dhaka. p. 78.

[5]. Bose, T. K. \& Som, M. G. (1986). Vegetable Crops in India. Naya Prokash, Calcutta, pp. 92-95.

[6]. Chigwe, C. F. B. (1991). Evaluation of Malawi pumpkin (Cucurbita moschata Duch ex Poir) germplasm collection. Lilongwe (Malawi), Aug. 1991. p. 35.

[7]. Doijode, S. D. \& Sulladmath, U. V. (1986). Genetic variability and correlation studies in pumpkin (Cucurbita moschata Poir.). Mysore Journal of Agricultural Sciences, 20(1), 59-61.

[8]. Formisano, G., Roig, C., Esteras, C., Ercolano, M. R., Nuez, F., Monforte, A. J. \& Picó, M. B. (2012). Genetic diversity of Spanish Cucurbita pepo landraces: an unexploited resource for summer squash breeding. Genetic Resources and Crop Evolution, 59, 1169-1184.

http://dx.doi.org/10.1007/s10722-011-9753-y

[9]. Ghobary, H. M. M. \& Ibrahim, Kh. Y. (2010). Improvement of summer squash through inbreeding and visual selection. J. Agric. Res. Kafer El-Sheikh Univ. 36, 340-350.

[10]. Gomez, K. A. \& Gomez, A. A. (1984). Statistical Procedures for Agricultural Research. (2nd Ed.). A Wiley Interscience Publication, John Wiley and Sons, Now York. pp. 188-206.

[11]. Gopalakrishnan, T. R. \& Peter, K. V. (1987). Evaluation of a few selected lines of pumpkin for local adaptability. Agricultural Research Journal of Kerala, 2(1), 119-121.

[12]. Hamid, M. N., Saha, M. C. \& Begum, R. A. (1991). Physio-morphology and yield of different ash gourd lines. Journal of Agricultural Science, 4(1), 51-55. 
[13]. Indiresh, B. T. (1982). Studies on genotypic and phenotypic variability in bitter gourd (Momordica charantia L.). Thesis Abstracts, 8(1), 52.

[14]. Islam, M. S., Sharmin, K., Khanam, D., Malik, M. A. \& Mosiul, A. M. M. (1993). Genetic variability and path analysis in cucumber. Bangladesh Journal of Plant Breeding and Genetics, 6(1), 45-51.

[15]. Nahar, M. A., Rabbani, M. G., Nisa, M. A. U. \& Karim, M. R. (2005). Genetic variability, correlation and path analysis in sweet gourd. J. Bangladesh Soc. Agric. Sci. Tech. 2(1\&2), 101-105.

[16]. Rahman, A. K. M. M., Das, M. K. \& Haque, M. M. (1986). Variability, correlation and path coefficient analysis in bottle gourd (Lagenaria vulgaris L.). Bangladesh Journal of Agricultural Science, 11(3), 13-19.

[17]. Rana, T. K., Vashistha, R. N. \& Pandita, M. L (1986). Genetic variability studies in pumpkin (Cucurbita moschata Poir.). Haryana Journal of Horticultural Sciences, 15(1-2), 71-75.

[18]. Rashid, M. (1993). Krishi Projukti Hatboi (in Bangla). Bangladesh Agricultural Research Institute, Joydebpur, Gazipur. p. 304.

[19]. Saha, R. R., Mitra, B. N., Hossain, A. E., Jamaluddin, M. \& Mosiul Hoque, A. M. M. (1992). Genetic variability, character association and path coefficient analysis in pumpkin (Cucurbita moschata L.). Bangladesh Horticulture, 20(1), 59-62.

[20]. Sharma, A., Vidyasagar, K. \& Pathania, N. K. (2000). Studies on combining abiity for earliness and marketable fruit yield in cucumber (Cucumis sativus L.). Himachal Journal of Agricultural Research, 26(1 \&2), 54-61.

[21]. Srivastava, V. K. \&. Srivastva, L. S. (1976). Genetic parameters, correlation coefficient and path coefficient analysis in bitter gourd (Momordica charantia L.). Indian Journal of Horticulture, 33(1), 66-70.

[22]. Tsivelikas, A. L., Koutita, O., Anastasiadou, A., Skaracis, G. N., Traka-Mavrona, E. \& KoutsikaSotiriou, M. (2009). Description and analysis of genetic diversity among squash accessions. Brazilian Archives of Biology and Technology, 52(2), 271-283. http://dx.doi.org/10.1590/S1516-89132009000200003

[23]. Vashistha, R. N., Partap, P. S. \& Pandita, M. L. (1983). Studies on variability and heritability in water melon (Citrullus lanatus (Thunb) Mansf.). Haryana Agricultural University Journal of Research, 13(2), 319-324.

[24]. Voster, I. H. J., Jansen van Rensburg, W., Van Zijl, J. J. B. \& Venter, S. L. (2007). The importance of traditional leafy vegetables in South Africa. AJFAND online, 7(4), 1-13.

http://www.ajfand.net/Volume7/No4/Vorster-IPGRI2-6.pdf

[25]. Yawalkar, K. S. (1985). Vegetable Crops of India. Agric. Horticultural Publishing House, Nagpur, India. pp. 178-182.

\section{How to cite this article?}

\section{APA (American Psychological Association)}

Nahar, M. A., Begum, S., Rabbani, M. G. \& Karim, M. R. (2016). Genetic variability and field performance of some sweet gourd (Cucurbita moschata Duch) accessions. Journal of Science, Technology and Journal of Science, Technology and Environment Informatics, 04(02), 301-312.

\section{MLA (Modern Language Association)}

Nahar, M. A., Begum, S., Rabbani, M. G. \& Karim, M. R. "Genetic variability and field performance of some sweet gourd (Cucurbita moschata Duch) accessions." Journal of Science, Technology and Environment Informatics, 04.02 (2016): 301-312.

\section{Chicago/Turabian}

Nahar, M. A., Begum, S., Rabbani, M. G. \& Karim, M. R. Genetic variability and field performance of some sweet gourd (Cucurbita moschata Duch) accessions. Journal of Science, Technology and Environment Informatics, 03, no. 02 (2016): 301-312. 